\title{
A new Anthrenus Geoffroy, 1762 species from Crete (Coleoptera: Dermestidae: Megatominae: Anthrenini)
}

\author{
JiŘí Háva ${ }^{1} \&$ ANDREAs HERRMANN ${ }^{2}$
}

\author{
${ }^{1}$ Forestry and Game Management Research Institute, \\ Strnady 136, CZ-156 00 Praha 5 - Zbraslav, Czech Republic \\ e-mail: jh.dermestidae@volny.cz \\ ${ }^{2}$ Bremervörder Strasse 123, 21682 Stade, Germany \\ e-mail: herrmann@coleopterologie.de
}

Háva, J. \& Herrmann, A.: A new Anthrenus Geoffroy, 1762 species from Crete (Coleoptera: Dermestidae: Megatominae: Anthrenini).

Abstract: A new species, Anthrenus (Nathrenus) obenbergeri sp. nov., collected in Greece: Crete is described, illustrated and compared with the similar species $A$. (N.) molitor Aubé, 1850. The new species differs by the structure of antennae and male genitalia.

Keywords: taxonomy, new species, Coleoptera, Dermestidae, Megatominae, Anthrenini, Anthrenus, Greece, Crete.

\section{Introduction}

The genus Anthrenus Geoffroy, 1762 consists of 10 subgenera: Anthrenodes Chobaut, Anthrenops Reitter, Anthrenus s. str., Helocerus Mulsant et Rey, Florilinus Mulsant et Rey, Nathrenus Casey, Peacockia Menier et Villemant, Ranthenus Mroczkowski, Setapeacockia Háva, and Solskinus Mroczkowski (Háva 2015). In general, this division has been established with regard to the total number of the antennomeres and antennal club, as well as the morphology of the scales and eyes (KADEJ \& HÁva 2015, Háva 2017). A new species recently collected in Greece: Crete is described herewith.

\section{Material and methods}

The size of the beetles or of their body parts can be useful in species recognition and thus, the following measurements were made:

total length (TL) - linear distance from anterior margin of pronotum to apex of elytra.

elytral width (EW) - maximum linear transverse distance. 
The following abbreviations refer to the collections, in which the examined materials are deposited:

AHEC - Andreas Herrmann, private collection, Stade, Germany

JHAC - Jiří Háva, Private Entomological Laboratory \& Collection, Únětice u Prahy Prague-West, Czech Republic

NHRS - Naturhistoriska Riksmuseet, Stockholm, Sweden

NMWC - Natural Sciences National Museum Wales, Cardiff, United Kingdom

PZPC - Petr Zahradník, private collection, Jesenice, Prague-West, Czech Republic

ZSPC - Zdeněk Švec, private collection, Praha, Czech Republic

Specimens of the species described here are provided with printed red labels with text as follows: „HOLOTYPE [or PARATYPE] Anthrenus (Nathrenus) obenbergeri sp. nov., J. Háva \& A. Herrmann det. 2021”.

\section{Results}

Anthrenus (Nathrenus) obenbergeri sp. nov.

(Figs. 1-4)

\section{Material examined:}

Holotype: Male: „Kreta V, Kaloudiana, T-E Leiler, 28.5.1985“, (NHRS).

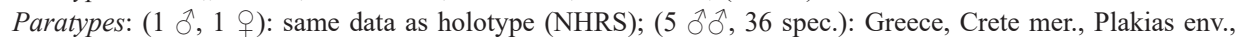
6-16.vii.2005, P. Zahradník lgt., (JHAC, 1 PZAC); (1 §̂, 1 ㅇ): Crete, Episkopi-beach, Rethino pref., 14-15.6.1992, J. Batelka lgt., (JHAC); (2 $\widehat{\partial} \hat{\jmath}, 1$ ㅇ): Greece, Crete, Panormo, 12.6.2004, Z. Švec lgt., (JHAC, ZSPC); (1 §): Greece, Crete, Kavallos, Chania, 03.06.1981, Hans Mühle leg., (AHEC); (1 §̂, 1 우): Greece, Crete, Plakias, 07.07.1986, leg. Suppantschitsch, (AHEC); (17 spec.): Crete, Agios Ioanis, 12.7.2005, P. Zahradník lgt., (PZAC, 2 JHAC); (1 spec.): Crete, Amudarion, 1983, M. Sláma lgt., P. Zahradník det. as A. molitor, (PZAC); (6 spec.): Greece: Crete, Rhethymnon, Platanes, 2-7.vii.2014, B. Levey, (NMWC); (2 spec.): Greece, Crete, Chania Prov., Aghia Marina, Olive grove, white umbelliferae, 15.vii.2006, B. Levey, (NMWC).

Description: Male body measurements (mm): TL 2.2, EW 1.5; color of the whole body deep black except the brown labrum and dark brown legs, oval, all surfaces covered with light grey scales; the scales touch each other but don't overlap. Eyes large with barely visible microsetae, with entire median margin. Ocellus distinctly present on frons. Pronotum broadest at its hind edges, narrowed towards the front, middle of the hind margin projectded towards the scutellum, lateral margins partly visible from above. Scutellum very small, broadly triangular, shiny without setae; elytra quite densely punctate, punctation barely visible beyond the scales. Antennae consist of 11 antennomeres, black to dark brown, antennal club black, with 3 antennomeres, compact (Fig. 2). Sternites I-V with similar punctation as on the elytra, covered in the same way with light grey scales. Legs dark brown with a few short brown setae and a row of thorns at the outer edge, the tarsi distinctly shorter than the tibiae. Aedeagus as in Fig. 3. Wing as in Fig. 4.

Sexual dimorphism: Female similar to male.

Variation in body size: TL 1.9-2.3 mm 

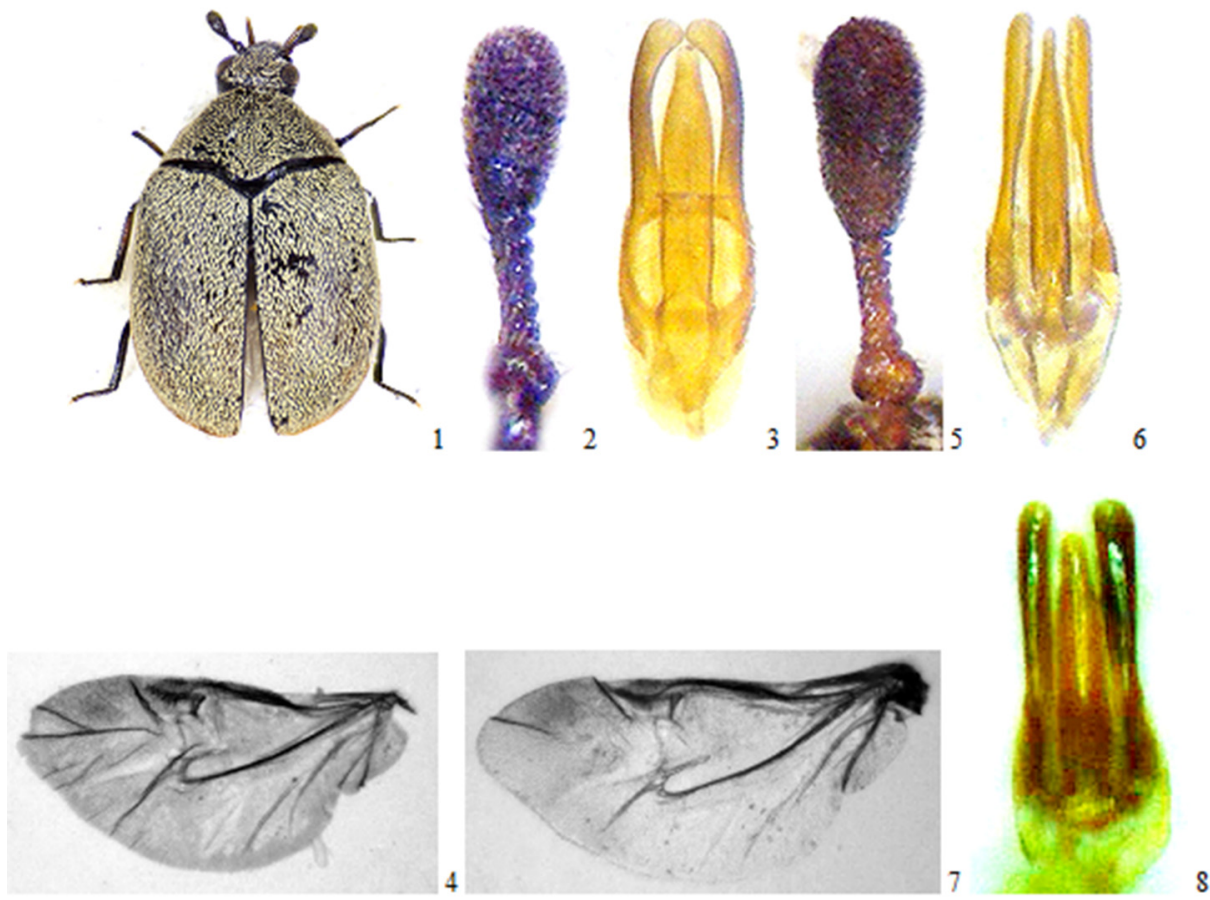

Figs. 1-8: Anthrenus (Nathrenus) obenbergeri sp. nov.: 1- habitus, dorsal view; 2- antenna of male; 3- male genitalia; 4- wing; Anthrenus (Nathrenus) molitor Aubé, 1850: 5- antenna; 6male genitalia; 7- wing; Anthrenus (Nathrenus) bulirschi Háva, 2000: 8- male genitalia

Differential diagnosis: Because of the morphological characters the new species belongs to the subgenus Nathrenus Casey, 1900, and according to the unicolorous white and milk scales on dorsal and ventral surfaces it looks extremely similar to $A$. (N.) molitor Aubé, 1850, but differs from that species by the structure of antenna and male genitalia, from next similar species $A$. (N.) bulirschi Háva, 2000, it differs by the structure of male genitalia.

Distribution: So far known from the island Crete in Greece.

Anthrenus (Nathrenus) molitor Aubé, 1850

(Figs. 5-7)

Material examined: Greece occ, Sivota, 85 km S Igoumenitsa, 20-27.5.2000, F. Kanther lgt., 11 spec., (JHAC); Greece, Preveza, 15.vi.1999, Z. Švec lgt., 4 spec., (JHAC); Greece, Taygetos Mts., Asaphigion, 14-15.vi.1974, Horák \& Švihla lgt., 45 spec., (JHAC).

Distribution: Known from Europe: Albania, Bulgaria, Croatia, France, Greece, Italy, Macedonia, Spain, Asia: Iraq, Israel, Lebanon, Turkey and Africa: Algeria, Egypt, Morocco, Tunisia. 


\section{Acknowledgements}

We are deeply obliged to the collectors for sparing the concerning specimens to the authors and to Larry Bezark (Sacramento, U.S.A.) for the revision of the English manuscript. The paper was supported by the Ministry of Agriculture of the Czech Republic, institutional support MZE-RO0118.

\section{References}

HávA, J. 2015: World Catalogue of Insects. Volume 13. Dermestidae (Coleoptera). - Leiden/Boston: Brill, xxvi $+419 \mathrm{pp}$.

Háva, J. 2017: A new Anthrenus Geoffroy, 1762 species from Morocco (Coleoptera: Dermestidae: Megatominae: Anthrenini). - Arquivos Entomolóxicos 17: 309-312.

KADEJ, M. \& HÁvA, J. 2015: A new species of Anthrenus Geoffroy, 1762 from China, with revised checklist of the Chinese species. - The Coleopterists Bulletin 69(3): 459-462. DOI: 10.1649/0010-065X-69.3.459 